Indonesian Journal of EFL and Linguistics

Vol. 5 No. 2, 2020

eISSN: 2503-4197, pISSN: 2527-5070

www. indonesian-efl-journal.org

\title{
Professional Development of English Teachers at a State Islamic Senior High School in Palembang
}

\author{
Rizki Fadhliyah \\ Universitas Sriwijaya \\ e-mail: kikifadhliyah@gmail.com \\ Soni Mirizon \\ Universitas Sriwijaya \\ e-mail: smirizon@unsri.ac.id \\ Ismail Petrus \\ Universitas Sriwijaya \\ e-mail: ismail_petrus@fkip.unsri.ac.id
}

\begin{abstract}
:
The objectives of this study were to investigate teachers 'professional development, the obstacles faced by the teachers, teachers' efforts to resolve the obstacles, and school support for the teachers in continuing professional development. To reveal the phenomenon, qualitative case study design was used. This study combined observation, questionnaires, and interviews in data collection. English teachers, vice-principal of the curriculum, teachers who taught other subjects, and students who had been taught by the English teachers were the participants of this study. Findings revealed that English teachers' professional development was good. The results also revealed that teachers' scientific publications were in the poor category. Innovative works for both English teachers were in the average category. Lack of time and information were the obstacles faced by the English teachers in continuing professional development. Teachers attempted to resolve the obstacles by looking for information needed through the internet. They also had discussions with other teachers to gain information for their knowledge. The school frequently conducted some programs related to teachers'
\end{abstract}


professional development and allowed them to attend professional development activities held by other institutions.

Keywords: obstacles, school supports, teacher efforts, teacher professionaldevelopment

\section{INTRODUCTION}

Education now is required to be in line with the increasing demand of globalization, so teachers are the core of development. Therefore, teachers need to develop their competencies in teaching and to have academic qualifications as well as the ability to achieve educational goals (Indrawati \& Octoria, 2016). Lisnawati (2018) states 21stcentury education as a period of knowledge, information, and technology. Moreover, teachers should participate in a variety of activities that promote lifelong learning (Bishop, 2016). In other words, teachers need to reach the increasing demand of globalization by continuing professional development.

A professional teacher is required to encourage students to become superior individuals who can survive and compete with others (Yulanto, Sudira, \& Aristya, 2018). Nowadays, teachers are expected to have a variety of roles (Bautista \& Ortega-Ruiz, 2017). Ball and Forzani (2009) claim that teacher's main duty is to develop students' cultural competence, communication skill, and relational sensitivity. Moreover, Makovec (2018) defines a professional teacher as an expert in the profession as well as in the field of pedagogical and psychological knowledge. Surya (2016) mentions that teacher professionalism is the combination of all of the qualities which are connected with educated, trained, and skilled teacher. Hermans, Sloep, and Kreijns (2017) state that teacher quality is correlated with student accomplishment. In short, teachers have an accelerating role in education development.

Improving the competencies of teachers and their professional development is important for producing qualified teachers (Snoek \& Klink, 2011; Qiu, 2015; Priajana, 2017).The Organization for Economic Co-operation and Development defines teacher professional development (PD) as activities to develop skills, knowledge, expertise, and other characteristics to create a professional teacher (OECD, 2009). Furthermore, related to professional development, Regulation of Minister of State Apparatus Empowerment and Bureaucratic Reform Number 16/2009 regarding Teachers' Functional Position and Credit Points, teachers' professional development in Indonesia divided professional development into three learning activities; self-development, scientific publications, and innovative works.

Studies showed some factors that influence teacher professional development. The problems come from the programs and activities which are not in touch with the specific need in teaching and learning (Rahman, 2016). Geographical problems and 
dissemination of information are other obstacles related to teacher professional development (Hartono, 2016; Sari, 2012). Indrawati and Octoria (2016) also mention similar problems such as teachers' lack of knowledge on professional development activity and teachers' unwillingness to conduct continuous professional development. Qureshi (2016) found that the challenges of teacher professional development were lack of access to resources, lack of professional support from management, and exaggerated workloads limited the learning opportunities. As a consequence, the English competency of Indonesian students is low.

The settlement of the obstacles in achieving professional development should be comprehensive and integrated. Hartono (2016) states the commitment from institution and teachers are required to make an effective professional development. Wulyani (2017) states teacher professional development policy and implementation documents must facilitate teachers' needs to maintain and improve their knowledge in English. Furthermore, Hilton, Hilton, Dole, and Goos (2015) explain that the school leaders have the capacity to change the environment and to provide input into the external domain of the teachers that influences their professional development.

There were some previous related studies that are closely related to this study. Katuuk and Marentek (2014) presented a study to find out teachers' perceptions of the impact of professional development programs on their teaching quality in the classroom. It was found that school should develop sustained professional development programs carefully. Moreover, teachers, policy-makers, and other authorized bodies should provide long-term ongoing professional development for primary school teachers. A study conducted by Hartono (2016) found that professional development activities may only last for a short period of time and have little impact on teachers' professional development. Wulyani (2017) believes opportunities for better professional development can be found in both personal and institutional levels. However, it was interesting to conduct similar research related to profes sional development. This study focused on the professional development of English teachers at a State Islamic Senior High School in Palembang, so the objectives were based on the following questions:

1. How was the professional development of English teachers at a State Islamic Senior High School in Palembang?

2. What were the obstacles faced by the English teachers at a State Islamic Senior High School in Palembang in professional development?

3. What were the teachers' efforts to resolve the obstacles to achieve professional development?

4. How did the school facilitate English teachers to achieve professional development?

\section{LITERATURE REVIEW}

\subsection{Professional Development}

Professional development is an element to improve the quality of education. Priajana (2017) states that professional development (PD) is an academic setting that enhances 
the quality of education effectively and efficiently. Chan (2004) divides the professional development of teachers into two aspects: cognitive and affective. The cognitive aspect refers to the acquisition of pedagogical knowledge and improved instructional skill. Moreover, the teachers' commitment and dedication to the teaching career is an important affective component in teacher development. Craft (2000) as cited in Rahman (2016) mentions the form of teacher professional development activities, for example, action research, self-directed study, using distance-learning materials, on-the-job coaching, mentoring or tutoring, school-based and off-site courses, job shadowing and rotation, peer networks, membership of a working party or task group, learning partnerships, school cluster projects, personal reflection, experiential 'assignments', collaborative learning, and information technology-mediated learning.

In summary, professional development is a process that teachers are supposed to gain experience, knowledge, and professional awareness continuously. In other words, teacher professional development is a mechanism to develop the quality of education, so teachers and schools also have an important role in supporting teachers to be professional.

\subsection{Teacher Professional Development in Indonesia}

Law No. 14/2005 of the Republic of Indonesia about Teachers and Lecturers explains that teachers are required for having a great chance to be more professional. Related to professional development, teachers need to develop their professionalism through professional development activities gradually. Regulation of Minister of State Apparatus Empowerment and Bureaucratic Reform Number 16/2009 regarding Teachers' Functional Position and Credit Points, teachers' professional development in Indonesia divided professional development into three learning activities; self-development, scientific publications, and innovative works.

Indrawati and Octoria (2016) mention self-development as teachers' effort to improve their ability and skill through functional education and training and teachers' collective activities. Moreover, based on Regulation of Minister of State Apparatus Empowerment and Bureaucratic Reform Number 16/2009, self-development consists of some competencies which are the competence in investigating and understanding the context, mastery of material and curriculum, mastery of teaching methods, competence in evaluating students and learning, mastery of information technology and computers (ICT), competency in facing innovation in the education system in Indonesia, competencies facing the current demands of the theory, and other competencies related to the implementation of additional tasks or other tasks relevant to the function of the school/Islamic schools. Similarly, Bunyamin (2016) states that teachers must have a good understanding on how to handle the class and the students, implement suitable methods and techniques, and evaluate their students using an appropriate measurement. Therefore, Patnaik and Davidson (2015) claim today's language teachers not only develop knowledge but also develop skills for a flexible teaching style adapted to the needs of the students. 
Merliza and Retnawati (2018) define scientific publications as writing activities based on action research results. Regulation of Minister of State Apparatus Empowerment and Bureaucratic Reform Number 16/2009 sets the competencies related to scientific publications in professional development. Scientific publications include presentation at the scientific forum, presentation/resource person at seminars, scientific workshops, colloquium or scientific discussion, and scientific publications resulting from research and innovative ideas in the field of formal education.

Innovative works are essential to provide an effective teaching and learning process. Indrawati and Octoria (2016) state innovative work is a work resulted from development, modification, or invention as a teacher's contribution to the improvement of learning process quality and the development of education. Similarly, Utami (2018) states innovative works mean the result of discovery and modification or development of existing work as teachers' contribution toward the improvement of learning quality at schools and toward the educational, science, and art field. Innovative works consist of the discovery of appropriate technology in complex and/or simple categories, development of complex and/or simple categories of artwork, making/modifying learning tools/ visuals/ practice complex and/or simple categories, and preparation of standards, guidelines, questions, and the like at the national and provincial levels.

Teacher professional development can be assisted in many ways. Indonesia teacher selfdevelopment, scientific publications, and innovative works are the most important factors which contribute to changes in student learning. The complexity of competencies required to be developed to create potential benefits for both teachers and students. In other words, to optimize the benefits of teacher professional development, teachers need to be equipped with support from the institution and government.

\section{RESEARCH METHODOLOGY}

This study employed qualitative research and case study design. The purpose of this research was to get the facts about the professional development of English teachers at a State Islamic Senior High School in Palembang in which the data were collected based on the observation, questionnaire, and interview.

\subsection{Participants}

The research site of this study was a State Islamic Senior High School in Palembang. The total number of participants was 24. They were two female English teachers, two female teachers who teach other subjects, the vice-principal of the curriculum, and 19 students who had been taught English at the school.

\subsection{Instruments}

The questionnaire was adapted from Regulation of Minister of State Apparatus Empowerment and Bureaucratic Reform Number 16/2009. The questionnaire had three components, self-development; scientific publications; innovative works, which consisted of 15 indicators. The questionnaire was designed with a four-point Likert Scale (always, usually, seldom, never). Questionnaire validity was checked by the experts and 
allowed to be used as the research instrument. This presented cross-validation with the data from interviews and observations to measure the credibility of the data.

In this study, semi-structured interviews and forum group discussion questions were adapted from Hartono (2016) and Rahman (2016). The semi-structured interviews and forum group discussions were conducted to the English teachers, vice-principal of the curriculum, teachers who taught other subjects, and students to see different perspectives of each participant about teacher professional development.

The classroom observation was focused on teacher self-development, scientific publication, and innovative works. They were conducted to measure how teachers' selfdevelopment, scientific publications, and innovative works indicators exist during one teaching and learning process. The observations results were analyzed and converted into the professional development of English teachers. These observations were also designed to triangulate the results of the questionnaire and interview.

\subsection{Data Analysis Procedures}

The results from the questionnaire, observation, and interview were analyzed. Firstly, the instruments were checked. Then, the researcher categorized strategies (coding and thematic analysis), connected the strategies (narrative analysis, and individual case study); memos, and displays. Specifically, in analyzing the data, the researcher scored, wrote, and described any matters concerning with professional development of English teachers at the State Islamic Senior High School in Palembang.

\section{FINDINGS}

The findings of this study are presented in order based on the sequence of the research questions related to professional development of English teachers, their obstacles faced by the teachers in continuing professional development, the efforts to resolve the obstacles, and the school support for them to achieve professional development.

\subsection{Professional Development of English teachers}

To gain the data related to the professional development of English teachers and its activities, questionnaires, interviews, and observations were used. Thus, the professional development of English teachers was divided into three activities; self-development, scientific publications, and innovative works.

\subsubsection{Self-development}

Self-development is the first element in teacher professional development. Based on the results of the questionnaire, it revealed that English teachers at the school had good professional development as shown in Figure 1 below. 


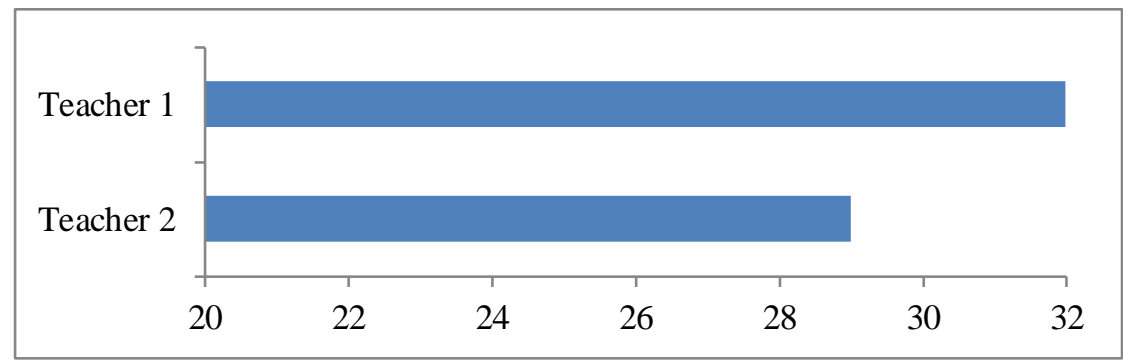

Figure 1. Self-development questionnaire results

English teacher $1(\mathrm{RM})$ achieved a higher score on this questionnaire which was 32 . Then, English teacher 2 (RW) achieved 29. It can be argued that, based on the results of the questionnaire, all of the English teachers had good self-development.

From the result of interviews, it was found that all teachers believed that their professional development was important to improve the quality of education, as shown in the following quotes.

To increase the ability and knowledge, by attending seminars or workshops and following other activities. (RM)

Because nowadays is very modern era, teachers usually search and learn the information from the internet... (RW)

The students had a similar opinion about their English teacher who was good and professional.

The teacher is already professional because she teaches firmly and easy to be understood. The teacher is always on time (Forum Group Discussion 3)

It is easy to understand the material when the English teacher explains it. In short, the English teacher is professional... (Forum Group Discussion 4)

The two English teachers agreed that self-development of the English teacher 1(RM) and English teacher 2 (RW) were good.

Findings from observation revealed that the teachers had mostly the competency of selfdevelopment. From the teaching and learning activities among the English teachers and the students, these teachers successfully directed the teaching and learning process by understanding the context and material. They always evaluated the students learning at the end of the meeting. Also, they gave the attention toward the innovation in the education system in Indonesia and the current demands theory by providing characterbuilding sessions during the teaching and learning process. During some observation, it was found that English teacher 2 (RW) directed students-centered learning process. Last, the competencies related to the implementation of additional tasks or other tasks relevant 
to the function of the Islamic schools, it was found that the school required the students to recite Al-Qur'an before the teaching and learning process. The observation findings were summarized in Table 1.

Table 1: Self-Development Observation

\begin{tabular}{lcc}
\hline \multicolumn{1}{c}{ Indicators } & Yes & No \\
\hline $\begin{array}{l}\text { Competencies in investigating and understanding the context in which the teacher } \\
\text { teaches. }\end{array}$ & $\sqrt{ }$ \\
Mastery of material and curriculum. & $\sqrt{ }$ \\
Mastery of teaching methods. & $\sqrt{ }$ \\
Competence in evaluating students and learning. & \\
Mastery of information technology and computers (ICT) & $\sqrt{ }$ \\
Competency in facing innovation in the education system in Indonesia. \\
$\begin{array}{l}\text { Competencies face the current demands of the theory. } \\
\text { Other competencies related to the implementation of additional tasks or other tasks } \\
\text { relevant to the function of the school/Islamic schools. }\end{array}$ & $\sqrt{ }$ \\
\hline
\end{tabular}

Two indicators did not exist during the observation. The first indicator was the mastery of teaching methods. The teacher had many options to choose from different teaching methods specifically designed for teaching and learning. Unfortunately, most of the time, these English teachers used lecturing teaching method. To be effective in promoting learning, they involved some teaching methods to invite students to be active. In other words, the lecturing teaching method encouraged students' passiveness. Second, the indicator that did not appear during the observation was mastery of information technology and computers (ICT). ICT plays an important role in learning. Unfortunately, during the observation, both English teachers did not use any communication device or application such as radio, television, telephones, computers, networks, hardware, and software or satellite systems in teaching. In summary, teachers needed to master the whole competencies of self-development to create the best teaching and learning process.

\subsubsection{Scientific Publications}

The questionnaire was also used to measure teachers' participation at the scientific forums and teachers' scientific publications resulting from research and innovative ideas. The results of questionnaire for teachers' scientific publications are shown in Figure 2. 


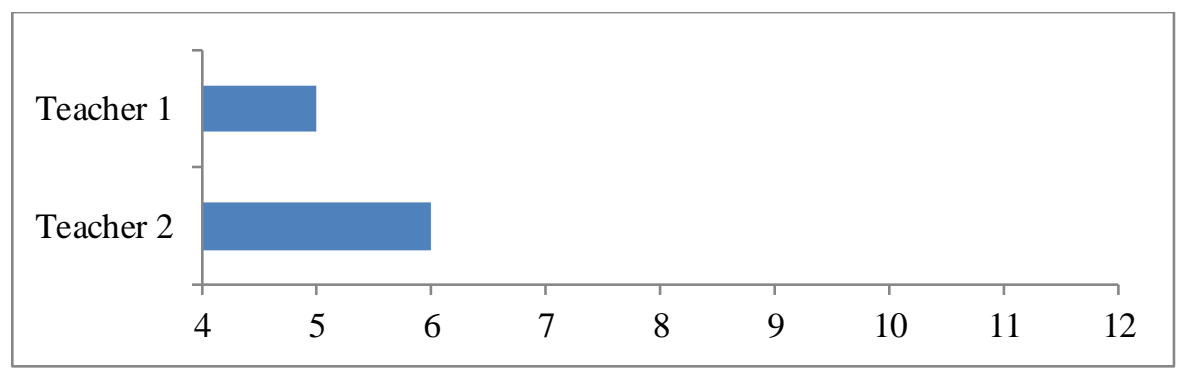

Figure 2.Scientific Publications questionnaire results

The results of the questionnaire showed that the English teachers' scores were only five and six. English teacher 1 (RM) got five, while English teacher 2 (RW) got six. In other words, they both obtained poor category of scientific publications.

Furthermore, based on the results of interviews, both teachers agreed that scientific publication activities such as the presentation at the scientific forums, seminars, scientific workshops, colloquium, or scientific discussion were rarely conducted. The English teachers answered:

Unfortunately, I have not been the speaker of a workshop, seminar, and scientific publication. (RM)

...we have limited time to take part in the scientific forums. (RW)

Those statements from these English teachers were supported by the teacher who teaches other subjects.

Teachers of each field of study have never been the speaker at seminars, workshops, and scientific discussions (RA)

However, both English teachers said that they had ever conducted classroom action research.

...I have done classroom action research. (RM)

It is classroom action research. This is one of the requirements for teachers' promotion. (RW)

It cannot be denied that teachers have many roles in the education field. Therefore, being the participant and presenter in the scientific forums or conducting scientific research were hardly done by the teachers as regularly as self-development activities.

The teachers' scientific publications results are summarized in the following Table 2. 
Rizki Fadhliyah, Soni Mirizon, Ismail Petrus

Table 2: Scientific Publications Observation Result

\begin{tabular}{lcc}
\hline \multicolumn{1}{c}{ Indicators } & Yes & No \\
\hline $\begin{array}{l}\text { Presentation at the scientific forum } \\
\text { As presentation/resource person at seminars, scientific workshops, }\end{array}$ & $\sqrt{ }$ \\
$\begin{array}{l}\text { colloquium, or scientific discussion. } \\
\text { Scientific publications resulting from research and innovative ideas in the } \\
\text { field of formaleducation. }\end{array}$ & $\sqrt{ }$ \\
\hline
\end{tabular}

Table 2 confirmed that all of the indicators of scientific publications did not exist during the observation. Moreover, during the observation, both English teachers never disseminated their research results through the presentation at regional, national, or international conferences. English teacher 1 (RM) and English teacher 2 (RW) did not have any contribution as the presenter at scientific workshops, colloquium, or scientific discussion. Last, both teachers did not conduct any scientific publications resulting from research and innovative ideas in the field of formal education.

\subsubsection{Innovative Works}

The questionnaire was also used to gain the information about teachers' contribution by converting their ideas or invention into useful products to support education. From the result of the questionnaire, the innovative work of English teachers was in the average category. The results of the questionnaire were shown in the Figure 3.

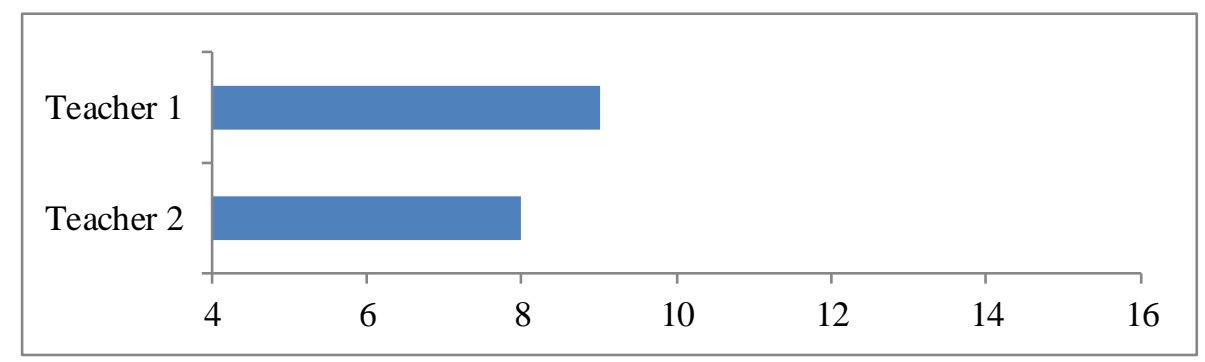

Figure 3. Innovative work questionnaire results

The score of the innovative work questionnaire of the English teacher 1 (RM) was eight and the English teacher 2 (RW) was nine. Thus, it can be concluded that the English teachers conducted innovative work activities infrequently.

Second, interviews were conducted to dig the information related to teacher innovative work. It showed that the teachers conducted some activities related to innovative works. They said:

...techniques in teaching and learning activities, how to make lesson plans, how to make learning media, syllabus, and so on. (RM)

...it is not only RPP or Syllabus. In professional development activities, it is also required to be able to create a fun learning atmosphere, then how to assess students' abilities in developing English lessons. (RW) 
Teachers who teach other subjects say that they have attended some activities related to teachers' innovative work.

...Digital score simulation (workshop), then lesson plan, syllabus, KKM, annual program, a semester program, and teaching material. (RA)

... The other teachers and I developed learning media. (FT)

Specifically, the students also said that the teachers used technology including projectors and social media.

In English lessons, the teacher uses a projector... (FGD 1)

The technology often used by teachers is usually a projector. (FGD 2)

...the teacher has mastered technology, information, and communication, but the use of technology in the learning process adapted to the learning material. (FGD 3)

Besides, the students also answered that the English teachers did not use learning tools in teaching English. Those students answered.

So far, there is no learning tool, hopefully, in the future, it will be available. (FGD 1)

The teacher does not provide any specific learning tools (FGD 6)

From the interview and forum group discussion results, it can be concluded that the English teachers have attended some professional development activities to develop their innovative work. They also had applied it while teaching and learning activities. But, they needed to develop the whole elements of innovative work to provide a better teaching and learning process.

The observation also showed that both teachers had the preparation of standards, guidelines, questions, and the like at the national and provincial levels. It can be confirmed that English teachers were required to provide guidelines and questions before the learning process was conducted. The innovative work observation results were summarized in Table 3 below.

Table 3: Innovative Works Observation Result

\begin{tabular}{|c|c|c|}
\hline Indicators & Yes & No \\
\hline The discovery of appropriate technology in complex and/or simple categories. & & $\sqrt{ }$ \\
\hline $\begin{array}{l}\text { Discovery/creation or development of complex and/or simple categories of } \\
\text { artwork. }\end{array}$ & & $\sqrt{ }$ \\
\hline $\begin{array}{l}\text { Making/modifying learning tools/visuals/ practice complex and/or simple } \\
\text { categories }\end{array}$ & & $\sqrt{ }$ \\
\hline $\begin{array}{l}\text { Preparation of standards, guidelines, questions, and the like at the national and } \\
\text { provincial levels. }\end{array}$ & $\sqrt{ }$ & \\
\hline
\end{tabular}

Indonesian Journal of EFL and Linguistics, 5(2), 2020 
During the observation, it was found that both English teachers had discovered or modified the preparation of standards, guidelines, questions, and the like at the national and provincial levels. English teacher 1 (RW) and English teacher 2 (RW) did not discover or use the appropriate technology and artwork in complex and/or simple categories. The English teachers did not use or modify learning tools in the class. Further, English teachers were hoped to be more enthusiastic to provide various teaching strategies and products. In short, the success of teaching and learning activities should be in line with the improvement of teachers' innovation. Moreover, the innovation in education was determined by the innovative activity of teachers, their attitude as innovative teachers, their ability to create or modify new educational products, and educational technologies.

The improvement of teachers' competence is a requirement in achieving good teaching and learning activity. English teacher 1 (RM) and English teacher 2 (RW) had the competency to explain the context and material by using the lecture method. Moreover, English teacher 1 (RM) focused as the facilitator to guide the students in the learning process, while English teacher 2 (RW) gave the opportunities for the students to be more independent. Unfortunately, both English teachers did not prepare, conduct, and attend any scientific forum and scientific research. Last, English teacher 1 (RM) and English teacher $2(\mathrm{RW})$ focused only on the preparation of standards, guidelines, questions, and the like at the national and provincial levels.

\subsection{Teachers' Obstacles in Continuing Professional Development}

The interview was conducted to English teachers, the teachers who teach other subjects, and the vice-principal of the curriculum affairs to find out teachers' obstacles in continuing professional development. Based on the interview results, it was found that the female teachers faced some difficulties in continuing professional development, as indicated below.

One of them is time. Sometimes if I attend a seminar or workshop, I have a teaching schedule at the same time. Another obstacle is information. Sometimes the information obtained by teachers regarding professional development activities is not fast enough. (RM)

...it is usually about time, because, the study times are from Monday to Saturday. So Sunday is the only free day. So the toughest challenge is time. Specifically, teacher professional development activities are held on school days. Besides, another challenge is the limited information obtained by teachers or schools. (RW)

Teachers who teach other subjects get the same obstacles.

It is mostly about time. I have to teach, then, attending some activities outside at the same time. (RA) 
....time is also an obstacle for teachers in participating in professional development activities. (FT)

The statements above were also supported by the vice-principal of the curriculum:

...We do not have enough time to attend all the scientific forums. It is also hard to conduct scientific research regularly because of the time limitation.(BY)

Based on the results of the interview, there were two obstacles faced by the English teachers in continuing professional development. There were related to the time and teaching schedule. Lack of information also became an obstacle faced by both English teachers.

\subsection{Teachers' Efforts to Resolve the Obstacles to Achieve Professional Development}

To achieve professional development, teachers need to resolve the obstacles. They need to improve their ability in problem-solving, communication, and self-management. Furthermore, the interview was conducted to obtain the information related to teachers' efforts to resolve the obstacles in achieving professional development. One English teacher said:

One of them is sharing the information with peer-teachers. It can be with MGMP participants too, then, through social media or advertisements. (RM)

The vice-principal of the curriculum added that teachers at his school are accustomed to continuing their professional development. The vice-principal of the curriculum answered:

....More than 95\%, in our school, all of the teachers are certified, so, they are qualified. Last, I think by joining more professional development activities, they would be much better in the future. (BY)

Continuing professional development is one of the teachers' priorities to create a better teaching and learning environment. There were several ways that the teachers did to resolve the obstacles. One of them is enhancing their ability and knowledge by finding out the information through the internet.

\subsection{The School Facilitation for English teachers in Continuing Professional Development}

Teacher professional development cannot rely only on the teachers themselves. The facilitation from the school is also an important factor that helps the English teachers to achieve professionalism. From the interview, these English teachers explained the school facilitation for English teachers in continuing professional development: 
The principal does not prohibit the teachers from participating in professional development activities. In other words, the school facilitates but the teacher must fulfill the duty as a teacher first. (RM)

The school has facilitated teachers to improve and develop their professionalism. Teachers are also given the right or freedom to teach in the class based on the lessons learned in the professional development activities that have been followed. (RW)

Teachers who teach other subjects answered:

One of them by facilitating and providing supportfor the teachers who want to develop their professionalism... (RA)

The school has provided opportunities and allowed the teachers to participate in activities... (FT)

The vice-principal responded related to the institutional support for the teachers to develop professional development was:

...encourage them by forwarding the invitations got from other institutions usually let them know some events, seminars, or workshops hosted by a university or other institutions and to arrange the schedule based on the schedule of the events...(BY)

The vice-principal of the curriculum also explained the activities that were provided to help the English teachers develop their professionalism.

Based on the schedule usually, in a year, actually in one semester, every six months, we have one workshop depends on the need of the teachers... (BY)

In conclusion, the school was concerned to support the English teachers to achieve their professionalism. The school actively approved teachers to attend professional development activities to increase and refresh their knowledge as long as they do not leave teaching as their main duty.

\section{DISCUSSION}

Based on the results of observation, questionnaire, and interview, it was found that selfdevelopment of English teachers was good. It can be confirmed that the English teachers could find ways of making each student successful in learning and successfully accommodated the different needs of students in their class. Darling-Hammond (2000) contends that teacher quality is more strongly related to students' achievement. Moreover, teachers have contributions to learners' success by providing content and language instruction (Mirizon, Wadham, \& Curtis, 2019). Even though most of the students claimed that their teachers were good, the teachers needed to improve and develop the whole competencies in self-development. In summary, the English teachers have the improvement of knowledge and skills as professional teachers. 
Indonesia has the potential in research and development (Wiryawan, 2014). Unfortunately, scientific publications of English teachers were categorized in the poor category. These facts were supported by Eliswan (2018). He stated that the small number of researchers was one of the challenges for science and technology research and development in Indonesia. Meanwhile, writing publications is an important part of the careers of many people in various fields (Mack, 2018).

The English teachers' innovative work in continuing professional development was in the average category. Teachers who have innovative work behavior are those who can work creatively and are able to provide the ideas and positive outcomes for the school (Baharuddin, Masrek, \& Shuhidan, 2019). Kalyani and Rajasekaran (2018) assumed the challenge to capture the students' attention and put across ideas even after the learning process. Unfortunately, to achieve the goals of teaching and learning activities, teachers need to fulfill all the indicators of innovative works.

Kanamu, Dyk, Chipeya, and Kilaha (2017) mentioned time constraints and lack of information and communication are the obstacles in continuing professional development. Based on the observation, it was found that the teachers had endless duties besides teaching. The major barrier for teachers in continuing professional development is related to conflict with the work schedule (Rashid, Rahman, \& Yunus, 2017). Another obstacle was the English teachers got difficulty to find out the information about professional development activities from the institutions where the program was conducted. Shelile and Hlalele (2014) added the lack of resources in schools di scourages the teachers who are willing to learn and serves as a scapegoat for those who are not willing to undertake professional development programs. Moreover, those obstacles were necessary to be resolved since teachers are required to be active for professional development activities.

There were several ways that the teachers did to resolve the obstacles. The teachers enhance their ability and knowledge by finding out the information through the internet. Geladze (2015) stated that almost all spheres of educational fields have been influenced by information technologies. Sangra and Gonzalez-Sanmamed (2010) added information and communication technologies (ICT) have huge benefits for improving the quality of education. The teachers also resolved the difficulties in continuing professional development through discussion with their other colleagues. DarlingHammond, Hyler, and Gardner (2017) stated that teachers can create communities that can improve their entire grade level, department, school, and/or district by working collaboratively.

There were also many activities regularly held by this school such as workshops and teacher training to develop the teachers' knowledge and skill from professional trainers and presenters. In line with Steyn (2009), schools should be professionally supportive of the teachers to have the resources they require and the opportunities to work together and learn from each other. Moreover, Merliza and Retnawati, (2018) suggest the school principal to provide, support, and motivate the teachers to constantly engage in various 
professional development activities. In summary, the school has great concerns about teacher professional development.

\section{CONCLUSION}

This study was aimed to investigate teachers' professional development. It also investigated the obstacles faced by the teachers, teachers' efforts, and school support for the teachers in continuing professional development. Based on Regulation of Minister of State Apparatus Empowerment and Bureaucratic Reform Number 16/2009, teacher professional development includes self-development, scientific publications, and innovative works. Findings from observation, questionnaire, and interviews showed that the teachers' self-development was good. However, English teachers' scientific publications were in the poor category. Last, teachers' innovative work was in the average category. Lack of time and poor information were the obstacles faced by the English teacher in continuing professional development.

Teachers attempted to resolve the obstacles by looking for information needed through the internet and discussion with other teachers to gain information for knowledge. School is required to have great efforts toward the teachers' professional development. In other words, the school had the attention toward teacher professional development. Furthermore, the school should conduct some programs related to teachers' professional development gradually and allow them to attend professional development activities held by other institutions. Last, teachers should develop their competency and knowledge continuously to create better education.

\section{REFERENCES}

Baharuddin, M. F., Masrek, M. N., \& Shuhidan, S. M. (2019). Innovative work behaviour of school teachers: A conceptual framework. IJAEDU-International EJournal of Advances in Education, 5(14), 213-221. https://doi.org/10.18768/ijaedu.593851

Ball, D. L., \& Forzani, F. M. (2009). The work of teaching and the challenge for teacher education. Journal of Teacher Education, 60(5), 497-511.

Bautista, A., \& Ortega-Ruiz, R. (2017). Teacher professional development: International perspectives and approaches. Psychology, Society, \& Education, 7(3).

Bishop, M. J. (2016). The Impact of Ongoing Professional Development on Math Achievement (Doctoral Dissertation). Carson Newman University, Tennessee, United States.

Bunyamin. (2016). Teacher professionalism: A study on teacher's professional and pedagogic competence at vocational high schools in the Northern Coastal of Jakarta. Indonesian Journal of Educational Research, 2(1), 77-84.

Chan, K. W. (2004). Teacher professional development: in-service teachers' motives, perceptions and concerns about teaching. Hong Kong Teachers' Centre Journal, 3, 56-71. 
Darling-Hammond, L. (2000). Teacher quality and student achievement: A review of state policy evidence. Education Policy Analysis Archive, 8(1), 1-44.

Darling-Hammond, L., Hyler, M. E., \& Gardner, M. (2017). Effective teacher professional development. Palo Alto, CA: Learning Policy Institute.

Eliswan, A. (2018, September 12). Indonesian scientific publications increased during 2017-2018 period. Antara News. Retrieved from https://en.antaranews.com/news/118470/indonesian-scientific-publicationsincreased-during-2017-2018-period

Geladze, D. (2015). Using the internet and computer technologies in learning/teaching process. Journal of Education and Practice, 6(2), 67-70.

Hartono, R. (2016). Indonesian EFL teachers' perceptions and experiences of professional development (Doctoral dissertation). Indiana University of Pennsylvania, Pennsylvania, Indiana.

Hermans, F., Sloep, P., \& Kreijns, K. (2017). Teacher professional development in the contexts of teaching English pronunciation. International Journal of Educational Technology in Higher Education, 14(23), 1-17.

Hilton, A., Hilton, G., Dole, S., \& Goos, M. (2015). School leaders as participants in teachers' professional development: The impact on teachers' and school leaders' professional growth. Australian Journal of Teacher Education, 40(12), 103-125. https://doi.org/10.14221/ajte.2015v40n12.8

Indrawati, C. D. S., \& Octoria, D. (2016). Continuous professional development to improve the teachers' competencies. In C. Budiyanto, I. Widiastuti, H. Zainnuri, H. E. Kurniawan, \& F. Kamal (Eds.), Strengthening IT and innovation of teacher training education in the era of global competitiveness (pp. 656-663). Surakarta: Faculty of Teacher Training and Education Sebelas Maret University.

Kalyani, D., \& Rajasekaran, K. (2018). Innovative teaching and learning. Journal of Applied and Advanced Research, 3(1), 23-25. https://doi.org/10.21839/jaar.2018.v3is1.162

Kanamu, L. G., Dyk, B. V., Chipeya, L., \& Kilaha, S. N. (2017). Barriers to continuous professional development participation for radiographers in Kenya. African Journal of Health Professions Education, 9(1), 17-20.

Katuuk, D.A., \& Marentek, L.K., M. (2018). Indonesian primary school teacher's perception of professional development programs: a case study. International Journal of Education and Research, 2(6), 629-634.

Lisnawati, I. (2018). The professionalism of Indonesian teachers in the future. Journal of Education, Teaching and Learning, 3(1), 28-33.

Mack, C. A. (2018). How to Write a Good Scientific Paper. Bellingham: SPIE PRESS.

Makovec, D. (2018). The teacher's role and professional development. International Journal of Cognitive Research in Science, Engineering and Education, 6(2), 33-45.

Merliza, P., \& Retnawati, H. (2018). Continuing professional development (CPD) for junior high school mathematics teachers : An evaluation study. REiD (Research and Evaluation in Education), 4(1), 79-93. 
Rizki Fadhliyah, Soni Mirizon, Ismail Petrus

Mirizon, S., Wadham, B., \& Curtis, D. (2019). Integrated content and language instruction: Lecturers' views and classroom instructional practices. Australian Journal of Teacher Education, 44(3), 42-60. https://doi.org/10.14221/ajte.2018v44n3.3

OECD. (2009). Creating Effective Teaching and Learning Environments. Talis. https://doi.org/10.1787/9789264068780-en

Patnaik, D. S., \& Davidson, L. M. (2015). The role of professional development in ensuring teacher quality. International Journal of English Language Teaching , 3(5), 13-19.

Priajana, N. (2017). Continuing professional development activities for English teachers. ELT Echo: The Journal of English Language Teaching in Foreign Language Context, 2(1).

Qiu, C. (2015). The professional development of teacher educators in Shanghai (Doctoral Dissertation). University of Glasgow, Scotland, United Kingdom.

Qureshi, N. (2016). Professional development of teacher educators: Challenges and opportunities (Doctoral Dissertation). University of Warwick, Coventry, England.

Rahman, A. (2016). Teacher professional development in Indonesia: The influences of learning activities, teacher characteristics and school conditions (Doctoral dissertation). University of Wollongong, New South Wales, Australia.

Rashid, R. A. B., Rahman, S. B. A., \& Yunus, K. (2017). Reforms in the policy of English language teaching in Malaysia. Policy Futures in Education, 15(1), 100112.

Sangra, A., \& Gonzalez-Sanmamed, M. (2010). The role of information and communication technologies in improving teaching and learning processes in primary and secondary schools. ALT-J: Research in Learning Technology, 18(3), 207-220.

Sari, E. R. (2012). Teacher professional development in an online learning community: a case study in Indonesia (Doctoral dissertation). Edith Cowan University, Perth, Australia.

Shelile, L. I., \& Hlalele, D. (2014). Challenges of continuing professional teacher development in Inclusive Lesotho Schools. International Journal of Educational Sciences, 7(3), 673-686. https://doi.org/10.1080/09751122.2014.11890230

Snoek, A. S., \& Klink. M. (2011). The quality of teacher educators in the European policy debate: Actions and measures to improve the professionalism of teacher educators. Professional Development in Education, 37 (5), 651-664.

Steyn, G. M. (2009). Effective implementation of continuing professional development for South African teachers. Acta Academica, 41(2), 256-279.

Surya, P. Student teacher recruitment in Indonesia: An initial step to promote teacher professionalism and teaching professionalization. In A. Komariah, A. G, Abdullah, A. Bayu, D. Nandiyanto, T. C. Kurniatun, R. Anggorowati, I. Gunawan, W. M. Wijaya, H. S. Nurlatifah (Eds.), Proceedings of the 6th International Conference on Educational, Management, Administration and Leadership (pp. 457-462). Yogyakarta, Indonesia: Atlantis Press. 
Utami, I. G. A. L. P. (2018). The alignment of perceptions and practices of effective English teaching by English teachers with different CPD involvement levels(Doctoral dissertation). Universitas Negeri Malang, Malang, Indonesia.

Wiryawan, K. G. (2014). The current status of science journals in Indonesia. Science Editing, 1(2), 71-75.

Wulyani, A. N. (2017). Professional development of English language teachers in Malang, Indonesia: Institutional and individual perspective (Doctoral dissertation). Victoria University of Wellington. Wellington, New Zealand.

Yulanto, D. M., Sudira, P., \& Aristya, P. D. (2018). Quality of continuous professional development for automotive engineering productive teachers. Jurnal Pendidikan Teknologi dan Kejuruan, 24(2), 192-197. 